\title{
Organic Carbon, and not Copper, Controls Denitrification in Oxygen Minimum Zones of the Ocean
}

\author{
Bess B. Ward, Caroline B Tuit, Amal Jayakumar, Jeremy J. Rich, James \\ Moffett, and S. W. A. Naqvi
}

Bess Ward, Corresponding Author

Department of Geosciences

Princeton University,

Princeton, NJ 08544, USA

Phone: 609-258-5150

Fax: 609-258-0796

Email: bbw@princeton.edu

Caroline B. Tuit

Current Address: Environmental Scientist, Gradient Corporation

20 University Road

Cambridge MA 02138, USA

Phone (617) 395-5575

Fax (617) 395-5001

Email: ctuit@gradientcorp.com

Amal Jayakumar

Department of Geosciences

Princeton University,

Princeton, NJ 08544, USA

Phone: 609-258-6294

Fax: 609-258-0796

Email: ajayakum@princeton.edu

Jeremy J. Rich

Current address: Center for Environmental Studies

Brown University

135 Angell St.

Box 1943

Providence, RI 02912, USA

Email: Jeremy_Rich@Brown.edu

James Moffett

Department of Biology

University of Southern California

Los Angeles, CA 90089-0371, USA

Phone: (213) 740-5626 
Email: jmoffett@usc.edu

S. W. A. Naqvi

National Institute of Oceanography

Goa, Dona Paula 403004

INDIA

Email: naqvi@nio.org 


\begin{abstract}
Incubation experiments under trace metal clean conditions and ambient oxygen concentrations were used to investigate the response of microbial assemblages in oxygen minimum zones to additions of organic carbon and copper, two factors which might be expected to limit denitrification in the ocean. In the oxygen minimum zones (OMZs) of the Eastern Tropical North and South Pacific, denitrification appeared to be limited by organic carbon; exponential cell growth and rapid nitrate and nitrite depletion occurred upon the addition of small amounts of carbon, but copper had no effect. In the OMZ of the Arabian Sea, neither carbon nor copper appeared to be limiting. We hypothesize that denitrification is variable in time and space in the OMZs in ways that may be predictable based on links to the episodic supply of organic substrates from overlying productive surface waters.
\end{abstract}

\title{
Key Words
}

Denitrification, oxygen minimum zone, carbon limitation 


\subsection{Introduction}

Conventional denitrification, the sequential reduction of nitrate to nitrite, then to nitric oxide and nitrous oxide and finally to dinitrogen gas, has long been considered the main loss term in the microbial $\mathrm{N}$ cycle. The process is performed mostly by heterotrophic bacteria that are facultatively anaerobic, utilizing oxidized $\mathrm{N}$ compounds for respiration when oxygen becomes limiting in soils and aquatic environments (Zumft 1997). Denitrification often occurs sequentially, both in cultures and in the environment, such that nitrate is first reduced completely to nitrite before gas production occurs, leading to transient accumulations of nitrite and nitrous oxide (Goering \& Cline 1970; Payne 1973; Naqvi et al. 2000; Betlach \& Tiedje 1981). The three major oceanic oxygen minimum zones are important sites for fixed $\mathrm{N}$ loss (as evidenced by nitrate deficits and excess $\mathrm{N}_{2}$ ). Nitrite and nitrous oxide occur in characteristic depth distributions in the OMZs, and these distributions are assumed to be the result of denitrification (Goering 1968; Naqvi \& Noronha 1991; Anderson et al. 1982). Early reports of denitrification

rates derived from incubations with ${ }^{15} \mathrm{NO}_{3}$ showed that the depth distribution of denitrification paralleled that of the nitrite concentration in the OMZ (Goering 1968). The mechanism leading to and maintaining these distributions has never been fully explained. An alternative pathway, leading to dintrogen gas via the oxidation of ammonium by nitrite, termed anammox (anaerobic ammonia oxidation), has been detected in many aquatic environments (Dalsgaard et al. 2005). Measurements of anammox and denitrification rates using isotope tracer experiments have detected both anammox and denitrification in marine sediments, but have detected predominantly anammox in the water column of marine oxygen minimum zones (Thamdrup et al. 2006; Hamersley et al. 
2007). Denitrifying bacteria are easily isolated from OMZ waters, and the signature genes of denitrification (nirS and nirK, which encode the iron and copper type nitrite reductases, respectively) are easily amplified from marine systems (Braker et al. 2000; Jayakumar et al. 2004), suggesting that denitrifiers are abundant and ubiquitous. Thus their apparent lack of activity in tracer experiments is perplexing.

The difficulties of explaining the distribution of denitrification intermediates in the OMZs and of detecting denitrification in situ led us to investigate environmental factors that might limit or control denitrification in seawater. The obvious possibilities include the distribution and concentration of oxygen, nitrate, organic carbon, and trace metals. Analysis of distributions of oxygen and nitrite in the OMZ regions (Morrison et al. 1999) shows that elevated nitrite is present only rarely in suboxic waters at oxygen concentrations $>2-4 \mu \mathrm{M}$. Thresholds of $2-4 \mu \mathrm{M} \mathrm{O}_{2}$ for the initiation of denitrification have been deduced from such correlations, but denitrification is observed, and the denitrification enzymes are induced, in cultures at much higher oxygen concentrations (Korner \& Zumft 1989). Nitrate is abundant in subsurface waters and is rarely completely depleted in the open ocean, so it does not appear to be limiting. Iron is involved in large numbers of enzymes in all except a few fermentative bacteria, and is thus potentially a limiting factor in the ocean. Iron is likely more available in sub- or anoxic waters than in oxygenated surface waters (Witter et al. 2000; Moffett et al. 2007), however, so seems less likely than copper to be a specific inhibitor of denitrification. Heterotrophic denitrifiers depend on a supply of organic matter, which, in the OMZ, could be supplied by vertical flux of planktonic production from shallower layers, or by horizontal transport. Carbon supply is generally correlated with regional 
denitrification rates (Liu \& Kaplan 1984). Severe oxygen depletion usually occurs between $80 \mathrm{~m}$ and $800 \mathrm{~m}$ and varies both temporally and spatially in intensity. The low sinking rate (McCave 1975; Mikkelsen \& Pejrup 2001) of small particles $(\sim 10-100 \mu \mathrm{m})$ implies that material from overlying production could reach the OMZ within a few days to weeks, so carbon inputs are expected to be episodic and linked to surface layer processes. Ocean circulation is partly responsible for the maintenance of low oxygen in subsurface waters, and may influence both the supply of carbon and the replenishment of oxygen. CFC estimates of the age of the water in the OMZ of the Arabian Sea are $20-$ 30 years (Howell et al. 1997).

Copper is a cofactor in two of the enzymes involved in the denitrification pathway, the copper containing nitrite reductase (NiRK) and nitrous oxide reductase (Nos). Thus it is possible that copper availability could specifically limit denitrification and account for the accumulation of nitrite and nitrous oxide by limiting the activity of these two enzymes. Low copper concentrations can indeed lead to nitrite or nitrous oxide accumulation in cultivated denitrifying bacteria (Granger \& Ward 2003), suggesting that the concentrations of copper found in OMZs might be low enough to limit natural assemblages of denitrifiers. In natural populations, copper limitation would likely result in the build up of nitrous oxide, rather than nitrite, which could be reduced by other denitrifying bacteria using the iron dependent nitrite reductase, NiRS.

In oceanic oxygen minimum zones, where about a third of marine denitrification takes place (Codispoti et al. 2001), total concentrations of copper are low, 0.5-2.0 nM (Danielsson 1980; Saagar et al. 1992; Boyle et al. 1977; De Baar et al. 1985). While these values are higher than dissolved iron in iron-limited areas of the oceans, most copper is 
organically complexed in the water column (Coale and Bruland, 1990; Moffett and Dupont, 2007). Moreover, in OMZ regions, copper speciation is strongly influenced by the presence of small concentrations of sulfides and thiols, which can be found in oxygen depleted waters (Al-Farawati \& van den Berg 1999; Laglera \& van den Berg 2003; Leal \& Van den Berg 1998). Concentrations of metal-sulfide complexes in the Arabian Sea OMZ are between 1-2 $\mathrm{nM}$ (Theberge et al. 1997) implying that most of the copper may be tightly bound in the form of inert sulfide complexes.

The primary goal of this work was to evaluate whether organic carbon or copper availability could limit denitrification in the $\mathrm{OMZ}$ regions and to investigate the potential for denitrification in waters that have been historically assumed to harbor high rates of denitrification. Here we report results of incubation experiments designed to investigate the response of natural microbial assemblages to increased copper and organic carbon concentrations. We visited the three most significant regions of water column denitrification in the global ocean, the Eastern Tropical South Pacific (ETSP) off the coast of Peru, the Eastern Tropical North Pacific (ETNP) off the coast of Mexico, and the Arabian Sea (AS), and performed "grow out" experiments under controlled conditions.

\subsection{Methods}

Incubation experiments were conducted during three cruises to the major oxygen minimum zones of the world oceans; the ETNP (R/V New Horizon November 2003), the Arabian Sea (R/V Sagar Kanya September-October 2004) and the ETSP (R/V Knorr October 2005). Station locations are listed in Table 1 and shown on the maps in Figure 1. Incubations were performed at two stations each in the ETNP and ETSP, and at four 
stations in the Arabian Sea (AS).

The water column hydrography was examined using a Seabird CTD for salinity, temperature, transmission, fluorescence and oxygen concentration. Niskin bottles on the CTD rosette were sampled for nitrate, nitrite and nitrous oxide and cell counts. Nitrite was measured on board ship colorimetrically (Parsons et al. 1984) either manually on a Shimadzu UV/VIS spectrophotometer (ETNP, ETSP) or by nutrient autoanalyzer (Arabian Sea). Nitrate samples from the Arabian Sea were also measured by nutrient autoanalyzer on board ship, but ETNP and ETSP nitrate samples were frozen and measured on land either by nutrient autoanalyzer (ETNP) or colorimetrically (Parsons et al. 1984) manually on a Shimadzu UV/VIS spectrophotometer. Nitrous oxide for ETNP and AS samples was measured using the sequential extraction method (Byrne \& Nicholas 1986) on board ship using a Shimadzu mini-2 gas chromatograph with an electron capture detector and a $2 \mathrm{~m}$ by $2.2 \mathrm{~mm}$ inner diameter Haysep D column (80/100 mesh). The column was set at ambient temperature while the injection port and detector were maintained at 50 and $300{ }^{\circ} \mathrm{C}$, respectively. The carrier gas was ultra high purity $\mathrm{N}_{2}$. The sample was extracted three times by shaking for 15 min with an equal volume of He gas. Each extraction $(0.5 \mathrm{ml})$ was injected into the GC. Analyses were standardized using ambient air and a 1 ppm nitrous oxide standard (Scott Gas).

Total copper was determined at three of the four Arabian Sea stations and two of the four ETNP stations (Table 1). Copper was determined by inductively coupled plasma mass spectroscopy (ICP-MS) on a Finnegan Element 2 instrument using the magnesium hydroxide coprecipitation method of Wu and Boyle (1998) with isotope dilution.

Seawater $(5 \mathrm{ml})$ was preserved with $2 \%$ glutaraldehyde, quick frozen in liquid 
nitrogen and stored at $-80^{\circ} \mathrm{C}$ for microbial abundance analysis on shore. Microbial cell abundance was determined by flow cytometry (Princeton Flow Cytometry Center) using Syto 13 dye (Invitrogen) and a Benton Dickinson FACSort with a $488 \mathrm{~nm}$ laser.

\section{1 Incubation Experiments}

Experimental depths were chosen on the basis of the nitrite concentration profile (Table 1). Water was collected in Teflon lined 30-L GoFlo bottles hung on trace metal clean Kevlar line. The bottles were plumbed with 1/4 inch acid cleaned Teflon tubing and pressurized with ultra high purity He gas while filling the incubation bags. Incubations were performed in 10-L trace metal clean gas tight trilaminate bags (Pollution Management Corporation, Oak Park, IL, USA). Each bag, fitted with a threeway Teflon stopcock, was cleaned with $10 \% \mathrm{HCl}$, rinsed with sterile MilliQ water, and then filled and flushed with filtered ultrapure He at least 6 times to eliminate any oxygen from possible headspace. Water from the GoFlo bottle was plumbed directly to the bag inside a HEPA filtered flow bench within a clean bubble.

Incubations were amended with approximately $5 \mu \mathrm{M}^{15} \mathrm{NO}_{3}^{-}$. Individual bags

received specific amendments of organic carbon (to a final concentration of $10 \mu \mathrm{g} \mathrm{L}^{-1}$ of 1:1 casamino acids and bactopeptone) and 2-4 nM copper; all additions were prepared under trace metal clean and sterile conditions. Bags were incubated at $10-14{ }^{\circ} \mathrm{C}$, depending on the ambient temperature, for 5 - 14 days and sampled each day for nitrite, nitrate, nitrous oxide and cell density. Copper additions to incubations increased the total concentrations by $2-4$-fold over ambient concentrations. On the ETNP cruise, $\mathrm{Cu}$ measurements of water subsampled from incubation bags filled with seawater show that 
the bags were not contaminating the samples with copper (data not shown).

\subsection{Results}

Hydrographic conditions and nutrient, oxygen and copper concentrations at the depths from which incubation samples were collected at shown in Table 1. Oxygen concentrations were not measured in the sample bottles; the CTD probe data represent initial conditions at the target sampling depth. Except for AS Station 17, all samples were collected from depths well within a broad OMZ, where oxygen concentration was relatively invariant over 10's - 100's of meters, so these in situ measurements are valid estimates for the initial conditions. These values are at the lower limit of precision and accuracy for CTD oxygen probes, but they are all consistent with levels at which denitrification is usually indicated by accumulation of nitrite (Morrison et al 1999), and nitrite was present initially in all samples except that at AS Station 17.

In the case of the ETSP, water was collected using individual Go-Flo bottles on a hydrowire, and weather conditions prevented precise resampling of the same depth. The initial nitrate concentration of $18 \mu \mathrm{M}$ represents the average measured in the individual bottles $(13-25 \mu \mathrm{M})$. The variability is due to sampling within the gradient of the nitrate deficit in the vicinity of $250 \mathrm{~m}$; oxygen concentrations were at the minimum detection level of the CTD probe between about 60 and $400 \mathrm{~m}$, so that this variation in nitrate concentration was not paralleled by any detectable variability in oxygen concentration.

AS Station 17 was the only station that was not located within a permanent oceanic OMZ; this coastal station had relatively low oxygen, but no nitrite initially, suggesting that denitrification had not commenced in situ. Nitrite concentrations at the 
other sampling depths were at levels usually associated with denitrification.

The Arabian Sea samples were substantially warmer than samples from equivalent depths in the ETNP and ETSP, but the minor variation in salinity among stations was probably not of biological significance.

In incubations in the ETNP and ETSP, DIN concentrations and cell numbers did not change in the control (no additions) and $\mathrm{Cu}$-only treatments over the course of $5-8$ day incubations (Figures 2, 3). The results shown are representative of the same patterns that were observed at other stations at these sites. The initial levels of nitrate and nitrite differed among incubations, especially in the ETSP, where each bag was filled from a separate Go-Flo cast, and weather prevented exact depth replication between casts. Whatever the initial levels, however, nitrate concentrations in the control treatments changed not at all in the ETNP and very slowly, if at all, in the ETSP.

In incubations that received amendments of carbon or carbon plus $\mathrm{Cu}$, a classic denitrification sequence occurred, like that observed in some denitrifying bacterial cultures (Zumft 1997) as nitrate is first depleted, leading to sequential accumulation and disappearance of intermediates nitrite and nitrous oxide. Nitrate was completely depleted within a day or two, nitrite accumulated transiently and then was completely depleted, and cell number increased rapidly during the nitrate and nitrite reduction stages (Figures 2, 3). Nitrous oxide was measured only in the ETNP, and it appeared transiently on the same time frame as the transient appearance of nitrite. For both nitrite and nitrous oxide, the events were rapid enough that the 24 hour sampling interval probably caused an underestimation of the true rates of production and consumption.

In striking contrast to the ETNP and ETSP, denitrification was observed in all 
treatments in bags incubated with water from the Arabian Sea OMZ. There was no difference between the bags that received carbon additions and those that did not. At all four stations in the Arabian Sea, controls and all treatments behaved essentially similarly and all exhibited the classical denitrification sequence (Figures 4 - 7) described for the carbon additions in the ETNP and ETSP experiments (Figures 2, 3). Replicate bags sometimes differed in the timing of the phases, but were consistent in the sense that slower nitrate depletion was accompanied by delayed nitrite accumulation and depletion. For example, at Station 2 in the AS (Figure 5), the second $\mathrm{Cu}$ treatment developed faster than the other three bags, but all followed the same pattern. At Station 17 (Figure 6), the two $\mathrm{Cu}$ treatments lagged behind the controls by about a day, but cell numbers in all treatments reached similar levels.

The nitrous oxide record is incomplete at Station 17 (Figure 6) because the experiment ended before the transient pulse of $\mathrm{N}_{2} \mathrm{O}$ had time to develop fully. The denitrification sequence was somewhat slower at Station 17 than in the ETNP and ETSP, and it appears that $\mathrm{N}_{2} \mathrm{O}$ was just beginning to accumulate at the end of the experiment; it would be expected to reach levels of a few hundred nM, as was observed in all other bag experpiments in which $\mathrm{N}_{2} \mathrm{O}$ was measured.

The apparent increase in nitrate between the first two time points in the AS experiments is due to the addition of a nitrate tracer, not in situ production of nitrate. Results from the tracer measurements will be reported elsewhere.

Even in bags that underwent rapid and complete denitrification, nitrate depletion was sometimes preceded by a lag of $1-2$ days. Cell number, however, increased dramatically in concert with the decrease in nitrate concentration. The growth rate of cell 
population in the bags, estimated from the exponential portion of the cell abundance time courses, ranged from $0.006 \mathrm{~d}^{-1}$ to $0.022 \mathrm{~d}^{-1}$ (generation times of 156 to $48 \mathrm{~h}$ ) (Table 2). Using the average cell number between adjacent time points, the maximum nitrate reduction rates for individual treatments ranged from 1.6 to $4.5 \times 10^{-8} \mu \mathrm{mol} \mathrm{cell}^{-1}$ day $^{-1}$ (Table 2) and from 0.73 to $2.110^{-8} \mu \mathrm{mol} \mathrm{cell}^{-1} \mathrm{day}^{-1}$ for nitrite reduction (Table 2). The maximum absolute nitrate removal rates, based on the single greatest change between adjacent time points, ranged from 6.8 to $20.6 \mu \mathrm{M} \mathrm{day}^{-1}$ (Table 2). When growth occurred, the highest growth rates were observed in the four ETSP in incubations to which additional carbon was added, and the lowest rate in the Arabian Sea incubations that underwent complete denitrification in the absence of carbon additions. Higher absolute nitrate reduction rates were observed in the ETSP and ETNP than in the AS, although nitrate reduction occurred in the ETSP and ETNP incubations only when carbon was added.

\subsection{Discussion}

\subsection{Denitrification rates}

The simplest interpretation of the incubation results is that organic carbon, and not copper, is an important limiting factor for denitrification in marine oxygen minimum zones. Both the ETSP and ETNP samples showed no DIN or cell number changes in the absence of added carbon, and the rapid changes that occurred in the presence of carbon suggest strong carbon limitation under ambient conditions. The Arabian Sea incubations, in contrast, were not carbon limited, as denitrification proceeded at comparable rates in controls and in bags to which either $\mathrm{Cu}$ or $\mathrm{C}$ or both had been added. 
The timing of the Arabian Sea cruise, immediately after the southwest monsoons, may have been a factor in this observation. During the cruise, several phytoplankton blooms were observed in the surface waters, and SeaWIFS data from September 2004 indicate that the blooms were widespread. This high surface productivity may have fueled rapid denitrification in the underlying suboxic waters. It may be that other times of year, denitrification in the Arabian Sea is carbon limited as in the other OMZ regimes, but the present results do not allow us to distinguish between spatial and temporal variability.

Denitrification rates (rate of nitrate removal) measured in the Arabian Sea incubations were very rapid (Table 2), equivalent on a per cell basis to rates observed in the carbon addition incubations in the ETSP (Table 2). With time points at approximately $24 \mathrm{~h}$ intervals, the resolution of our computed growth rates and DIN reduction rates is limited. Nevertheless, a reasonable exponential fit for $3-4$ points could be obtained for the cell numbers, suggesting that most of the assemblage underwent exponential growth in the bags. The generation times computed for the incubations are longer than usually observed under culture conditions (on the order of 5-45 hr; Otte et al. 1996; Ogilvie et al. 1997), but the curve fits implied that growth commenced almost immediately in some incubations (e.g., ETSP and AS Station 17).

The absolute rates of nitrate reduction measured in the Arabian Sea experiments with no carbon additions were lower than those observed in the ETSP and ETNP after carbon addition. In the ETSP and AS, except for AS Station 17, nitrate reduction rates were roughly correlated with growth rate of cells in the incubation. The observed rates are rapid enough to deplete the ambient nitrate in a few days and clearly are not 
representative of rates that occur in the ocean (Table 2). One of the highest reported rates in the literature $\left(2.4 \mu \mathrm{M} \mathrm{d}^{-1}\right.$; Castro-Gonzalez \& Farias 2004) is still much lower than observed in the bags but most other reported rates for all three OMZs are lower by $3-4$ orders of magnitude (e.g., Devol et al. 2006; Naqvi \& Shailaja 1993; Cline \& Richards 1972; Codispoti et al. 1986). In the OMZs, nitrate is never totally depleted and a seasonally and spatially variable secondary nitrite maximum persists. This indicates that although denitrification proceeds to completion (i.e., $\mathrm{N}_{2}$ excess accumulates), intermediates persist even at those sites where the process was apparently not carbon limited. The persistence of denitrification intermediates in nature may be due to the episodic nature of organic carbon supply.

The high rates and occurrence of complete nitrate depletion must be attributed to some kind of incubation artifact, although the nature of the artifact is not clear. The amount of nitrate reduction that occurred would deplete the total nitrate pool in no more than a few days. In the bags, the nitrate was drawn down to zero, and must have been accompanied by organic carbon oxidation. The measured nitrate reduction rates in Table 2 would imply $\mathrm{C}$ oxidation rates of $47-206 \mu \mathrm{M} \mathrm{C} \mathrm{d}^{-1}$ assuming $\mathrm{C}: \mathrm{N}$ of 7 to 10 . This consumption far exceeds the amount of labile carbon that was added to the plus $\mathrm{C}$ treatments in the ETSP and ETNP, so the added carbon must have activated bacterial metabolism to increase utilization of the in situ DOC pool. The particulate carbon flux in this region of the water column is on the order of $0.5-1 \mathrm{mmol} \mathrm{m}^{-2} \mathrm{~d}^{-1}$ (Lee et al. 1998; Honjo et al. 1999). Maximum observed DOC concentrations at OMZ depths are on the order of 100 - $200 \mu \mathrm{M}$ (Kumar et al. 1999; Naqvi et al. 2002). Neither N nor C removal 
rates of this order are compatible with the $\mathrm{C}$ and $\mathrm{N}$ supply rates implied by these fluxes and in situ concentrations.

Containment artifacts, such as increases in total cell number and abundance of colony forming units, can be detected after incubations as short as $5 \mathrm{hr}$ (Ferguson et al. 1984). In both the ETNP and the ETSP, however, incubations without $\mathrm{C}$ additions did not change for several days; therefore, simply enclosing the water in an incubation bag is not sufficient to induce denitrification or cell abundance increases if $\mathrm{C}$ is limiting. A similar result was reported in control experiments designed to test the effect of carbon additions on denitrification in the Baltic Sea (Brettar \& Rheinheimer 1992).

On the other hand, even when denitrification commenced without additions, it was often preceded by a lag of 20 to $70 \mathrm{hr}$ (Figs 2 - 7). In the ETNP and ETSP, it might be reasonable to ascribe the lag to acclimatization by a natural population to a new carbon source. The ETSP microbial community, however, did not show a lag, commencing exponential growth by the first time point (Figure 3, Table 2) and the Arabian Sea incubations exhibited a lag even when carbon was not added to the incubations.

Oxygen contamination might be suspected in causing the lag, but we have no evidence that such contamination occurred. On later cruises, oxygen concentrations in the initial sampling bottles, in the initial bags and in the bags after 8 days of incubation were measured using a flow through microelectrode. No oxygen and no changes in the oxygen levels were detected in any of the 40 or so bags tested (unpublished data). In previous bag incubation experiments, we measured oxygen in the bags periodically over several days using the microcolorimetric method and did not observe changes in concentration at the 
low micromolar level (Ward et al. 2005).

One of the control incubations from Arabian Sea Station 1 (Figure 4) shows what happens when a bag develops a leak and becomes contaminated with oxygen. Between 89 and $120 \mathrm{~h}$ there was a rapid increase in cell number and a rapid decrease in nitrite and nitrate. Such an increase in cell number did not occur during the initial lag in denitrification, which argues that the lag is not caused by oxygen contamination. Indirectly, it can be argued that if oxygen were the cause of the cell growth we would expect significant growth before the onset of denitrification. The timing of cell growth, however, generally coincided with the onset of denitrification, and the same lag was evident in both sets of curves.

If low levels of oxygen were present in the bags initially, we might hypothesize an analogy with the diauxic lag observed in water treatment systems in which aerobic and anaerobic conditions are alternated on cycles of up to several hours (Liu et al. 1998). Such systems usually experience a lag of up to several hours before denitrification resumes after exposure to oxygen. The proposed explanation for the diauxic lag is that after switching from aerobic to anaerobic growth, substantial time is required to build up the activity of denitrifying enzymes. The length of the lag before denitrification commenced was dependent upon the length of the preceding aerobic period, which influences the nitrate flux needed to induce and stimulate denitrifying enzyme activity (Hamilton et al. 2005).

It may be that the apparent lag period preceding rapid denitrification in the bags is the actual in situ condition and the commencement of rapid denitrification is the artifact. The incubation conditions may increase dentrification rates by wall effects, elimination of 
grazers, isolation from oxygen diffusion or trapping of organic particles that otherwise would have rapidly fallen out of the denitrification zone. Wall effects also may increase denitrification rates by providing an attachment surface. The usual approach for minimizing wall effects is to increase the volume of the incubation, but at 8 to $10 \mathrm{~L}$ the size of these incubations exceeds that usually employed to limit wall effects and increasing the incubation size any farther would be methodologically unfeasible. If wall effects are the dominant factor in determining rates in 10-L bags, then most conventional incubation experimental designs must be reevaluated.

Undersampling of zooplankton grazers can lead to artificial enhancement of rates in incubations but microbial grazers would have been present in the unfiltered bag incubations. The isolation of a water sample from oxygen diffusion may also artificially increase the dentrification rate, but does not explain the lack of cell growth during the initial lag. The samples were collected from a region of the $\mathrm{OMZ}$ in which oxygen concentration gradients are minimal, so resupply of oxygen by diffusion would never be significant under in situ conditions. Horizontal advection, especially in the AS, could, however, introduce water with variable nitrite and oxygen conditions, thus preventing long term anoxia at the $\mathrm{OMZ}$ depth and preventing complete acclimation of the microbial community.

The trapping of rapidly falling organic particles may increase initial carbon availability, but would be expected to be highly variable among sampling bottles. This is not consistent with the unambiguous treatment effects we observed. There does not appear to be a satisfying explanation for the extreme rapidity of the observed denitrification rates, nor for the lag that preceded denitrification in both amended and 
control samples.

Anammox has also been reported in the ETSP, where it was more important than denitrification (Thamdrup et al. 2006, Hamersley et al. 2007), and is likely to be important in all the OMZs. The in situ rates of anammox or denitrification might be below the detection limit of the DIN measurements used to infer denitrification rates in the bag assays reported here. Lags in the onset of denitrification were observed in the oxygen minimum zone of the ETSP, while there was no lag in anammox activity (Thamdrup et al. 2006, Hamersley et al. 2007). On the other hand, anammox was not important compared to denitrification in the Arabian Sea (Nicholls et al. 2007). These studies used the ${ }^{15} \mathrm{~N}$ isotope pairing method, which is a sensitive method for direct detection of anammox and denitrification. Regardless of the relative importance of anammox and denitrificaton, the experiments reported here were designed to evaluate factors that may limit the activity and growth of denitrifying bacteria in OMZs (copper is required specifically by denitrifying enzymes and organic carbon is not utilized by the autotrophic anammox organisms).

\subsection{Copper Speciation and Bioavailability}

There was no indication in this study that copper was limiting denitrification rates or influencing the production of nitrous oxide. The control and copper addition treatments behaved essentially the same in all three oxygen minimum zones. $\mathrm{Cu}$ speciation data from these stations (Moffett, unpublished) show that $\mathrm{Cu}$ was tightly

complexed by organic ligands, with free $\mathrm{Cu}^{2+}$ as low as $10^{-14} \mathrm{M}$ in the ETNP and $10^{-18} \mathrm{M}$ in the Arabian Sea far below the limiting value previously reported for denitrifiers 
(Granger \& Ward 2003). However, those ligands were saturated by $\mathrm{Cu}$ additions of 2-4 $\mathrm{nM}$, resulting in free $\mathrm{Cu}$ increasing by several orders of magnitude. Therefore, $\mathrm{Cu}$ added in the incubations was expected to be much more bioavailable to denitrifiers. The absence of any effect of the added $\mathrm{Cu}$ suggests that denitrifiers are able to utilize naturally occurring $\mathrm{Cu}$ even when it is tightly complexed. Prokaryotes have evolved strategies to acquire organically complexed iron, such as the production of siderophores, and it is possible that similar mechanisms may be employed by denitrifiers with respect to copper. Because denitrifiers appear to be able to take up the copper they require, even at very low ambient conditions, and the lack of stimulation by increased concentrations of bioavailable copper, we conclude that copper is not the controlling variable for denitrification in the OMZs.

\subsection{Conclusion}

Organic carbon availability does appear to be limiting in the ETNP and ETSP. These results lead to the hypothesis that denitrification in the OMZs is linked to the supply of organic material, most likely through episodic transport of sinking material from productive overlying waters. A more systematic investigation of denitrification rates and regulation in space and time will be required to distinguish between fundamental geographical contrasts between the AS and the ETNP and ETSP and the denitrification response to seasonally varying carbon inputs in all three regions. 
Figure Captions

\section{Figure 1}

Map of station locations in the three major OMZ regions.

\section{Figure 2}

DIN and cell concentrations in incubation experiments from the ETNP Station 15.

Copper additions were $3 \mathrm{nM}$ total copper. Treatments included one control (no additions) (open diamonds), one copper-only control (open triangles), three carbon additions (filled diamonds), and three carbon + copper additions (filled triangles).

\section{Figure 3}

DIN and cell concentrations in incubation experiments from the ETSP Station 9. Copper additions were $2 \mathrm{nM}$ total copper. Treatments included two controls (no additions) (open diamonds), two copper additons (open triangles), two ammonium additions ( $4 \mu \mathrm{M})$ (open circles), two carbon additions (filled diamonds), and two carbon + copper additions (filled triangles).

\section{Figure 4}

DIN and cell concentrations in incubation experiments from the Arabian Sea Station 1. Copper additions were $2 \mathrm{nM}$ total copper. Treatments included two controls (no additions) (open diamonds), two copper additions (open triangles), two carbon additions (filled diamonds), and two carbon + copper additions (filled triangles). 


\section{Figure 5}

DIN and cell concentrations in incubation experiments from the Arabian Sea Station 2. Copper additions were $2 \mathrm{nM}$ total copper. Treatments included two controls (no additions) (open diamonds) and two copper additions (open triangles).

\section{Figure 6}

DIN concentrations in incubation experiments from the Arabian Sea Station 17 for nitrate, nitrite, nitrous oxide and cell density. Copper additions were $2 \mathrm{nM}$ total copper. Treatments included two controls (no additions) (open diamonds) and two copper additions (open triangles).

\section{Figure 7}

DIN concentrations in incubation experiments from the Arabian Sea Station 23 for nitrate, nitrite, nitrous oxide and cell density. Copper additions were $2 \mathrm{nM}$ total copper. Treatments included two controls (no additions) (open diamonds) and two copper additions (open triangles). 


\section{References}

Al-Farawati R, C M G van den Berg (1999) Metal-sulfide complexation in seawater. Marine Chemistry 63:331-352

Anderson J J, A Okubo, A S Robbins, F A Richards (1982) A model for nitrite and nitrate distributions in oceanic oxygen minimum zones. Deep-Sea Research 29:1113 1140

Betlach M R, J M Tiedje (1981) Kinetic Explanation For Accumulation Of Nitrite, Nitric-Oxide, And Nitrous-Oxide During Bacterial Denitrification. Applied And Environmental Microbiology 42:1074-1084

Boyle E A, F Schlater, J M Edmond (1977) The distribution of dissolved copper in the Pacific. Earth and Planetary Science Letters 37:38-54

Braker G, J Z Zhou, L Y Wu, A H Devol, J M Tiedje (2000) Nitrite reductase genes (nirK and nirS) as functional markers to investigate diversity of denitrifying bacteria in Pacific northwest marine sediment communities. Applied and Environmental Microbiology 66:2096-2104

Brettar I, G Rheinheimer (1992) Influence Of Carbon Availability On Dentrification In The Central Baltic Sea. Limnology And Oceanography 37:1146-1163

Byrne M D, D J D Nicholas (1986) Multiple-phase equilibration headspace analysis for the determination of $\mathrm{N}_{2} \mathrm{O}$ an $\mathrm{N}_{2}$ during bacterial denitrification. Analytical Biochemistry 154:470-475

Castro-Gonzalez M, L Farias (2004) $\mathrm{N}_{2} \mathrm{O}$ cycling at the core of the oxygen minimum zone off northern Chile. Marine Ecology-Progress Series 280:1-11

Cline J D, F A Richards (1972) Oxygen Deficient Conditions And Nitrate Reduction In Eastern Tropical North-Pacific Ocean. Limnology And Oceanography 17:885-900

Coale K H, K W Bruland (1990) Spatial and temporal variability in copper complexation in the North Pacific. Deep-Sea Research 37:317-336

Codispoti L, J Brandes, J Christensen, A Devol, S Naqvi, H Paerl, T Yoshinari (2001) The oceanic fixed nitrogen and nitrous oxide budgets: Moving targets as we enter the anthropocene? Scientia Marina 65:85-105

Codispoti L A, G E Friederich, T T Packard, H E Glover, P J Kelly, R W Spinrad, R T Barber, J W Elkins, B B Ward, F Lipschultz, N Lostaunau (1986) High Nitrite Levels Off Northern Peru - A Signal Of Instability In The Marine Denitrification Rate. Science 233:1200-1202

Dalsgaard T, B Thamdrup, D E Canfield (2005) Anaerobic ammonium oxidation (anammox) in the marine environment. Research In Microbiology 156:457-464

Danielsson L G (1980) Cadmium, cobalt, copper, iron, lead, nickel and zinc in Indian Ocean water. Marine Chemistry 8:199-215

De Baar H J W, M P Bacon, P G Brewer, K W Bruland (1985) Rare earth elements in the Pacific and Atlantic oceans. Geochimica et Cosmochimica Acta 49:1943-1959

Devol A H, A G Uhlenhopp, S W A Naqvi, J A Brandes, D A Jayakumar, H Naik, S Gaurin, L A Codispoti, T Yoshinari (2006) Denitrification rates and excess nitrogen gas concentrations in the Arabian Sea oxygen deficient zone. Deep-Sea Research 53:1533-1547 
Ferguson R L, E N Buckley, A V Palumbo (1984) Response Of Marine Bacterioplankton To Differential Filtration And Confinement. Applied And Environmental Microbiology 47:49-55

Goering J J (1968) Denitrification In Oxygen Minimum Layer Of Eastern Tropical Pacific Ocean. Deep-Sea Research 15:157-164

Goering J J, J D Cline (1970) A Note On Denitrification In Seawater. Limnology And Oceanography 15:306-\&

Granger J, B B Ward (2003) Accumulation of nitrogen oxides in copper-limited cultures of denitrifying bacteria. Limnology and Oceanography 48:313-318

Hamersley M R, G Lavik, D Woebken, J E Rattray, P Lam, E C Hopmans, J S S Damste, S Kruger, M Graco, D Gutierrez, M M M Kuypers (2007) Anaerobic ammonium oxidation in the Peruvian oxygen minimum zone. Limnology And Oceanography 52:923-933

Hamilton R, A Casasus, M Rasche, A Narang, S A Svoronos, B Koopman (2005) Structured model for denitrifier diauxic growth. Biotechnology And Bioengineering 90:501-508

Honjo, S, J Dymond, W Prell, V Ittekkot (1999) Monsoon-controlled export fluxes to the interior of the Arabian Sea. Deep-Sea Research 46:1859-1902

Howell E A, S C Doney, R A Fine, D B Olson (1997) Geochemical estimates of denitrification in the Arabian Sea and the Bay of Bengal during WOCE. Geophysical Research Letters 24:2549-2552

Jayakumar D A, C A Francis, S W A Naqvi, B B Ward (2004) Diversity of nitrite reductase genes (nirS) in the denitrifying water column of the coastal Arabian Sea. Aquatic Microbial Ecology 34:69-78

Korner H, W G Zumft (1989) Expression of denitrification enzymes in response to the dissolved oxygen level and respiratory substrate in continuous culture of Pseudomonas stutzeri. Applied and Environmental Microbiology 55:1670-1676

Kumar, M D, A Rajendran, K Somasundar, B Haake, A Jenisch, Z Shuo, V Ittekkot, B N Desai (1990) Dynamics of dissolved organic carbon in the northwestern Indian Ocean. Marine Chemistry 31:299-316

Laglera L M, C M G van den Berg (2003) Copper complexation by thiol compounds in estuarine waters. Marine Chemistry 82:71-89

Leal M F C, C M G Van den Berg (1998) Evidence for strong copper(I) complexation by organic ligands in seawater. Aquatic Geochemistry 4:49-75

Lee C, D W Murray, R T Barber, K O Buesseler, J Dymond, J I Hedges, S Honjo, S J Manganini, J Marra, DC Moser, M L Peterson, W L Prell, S G Wakeham (1998) Particulate organic carbon fluxes: compilation of results from the 1995 US JGOFS Arabian Sea process study. Deep-Sea Research 45:2489-2501

Liu K K, I R Kaplan (1984) Denitrification Rates And Availability Of Organic-Matter In Marine Environments. Earth And Planetary Science Letters 68:88-100

Liu P H, G G Zhan, A Svoronos, B Koopman (1998) Diauxic lag from changing electron acceptors in activated sludge treatment. Water Research 32:3452-3460

Luther G W (1991) Sulfur and iodine speciation in the water column of the Black Sea. In: Izdar E, Murray JW (eds) Black Sea Oceanography. Kluwer Academic Publishers, The Netherlands, p 187-204

McCave I N (1975) Vertical Flux Of Particles In Ocean. Deep-Sea Research 22:491-502 
Mikkelsen O A, M Pejrup (2001) The use of a LISST-100 laser particle sizer for in-situ estimates of flee size, density and settling velocity. Geo-Marine Letters 20:187195

Moffett J W, T J Goepert, S W A Naqvi (2007) Reduced iron associated with secondary nitrite maxima in the Arabian Sea. Deep-Sea Research Part I-Oceanographic Research Papers 54:1341-1349

Moffett, J W. and C L Dupont (2007) Cu Complexation by organic ligands in the sub arctic NW Pacific and Bering Sea. Deep Sea Research Part I-Oceanographic Research Papers 54:586-595

Morrison J M, L A Codispoti, S L Smith, K Wishner, C Flagg, W D Gardner, S Gaurin, S W A Naqvi, V Manghnani, L Prosperie, J S Gundersen (1999) The oxygen minimum zone in the Arabian Sea during 1995. Deep-Sea Research Part IITopical Studies In Oceanography 46:1903-1931

Naqvi S W A, D A Jayakumar, P V Narvekar, H Naik, V Sarma, W D'Souza, S Joseph, M D George (2000) Increased marine production of N2O due to intensifying anoxia on the Indian continental shelf. Nature 408:346-349

Naqvi S W A, R J Noronha (1991) Nitrous oxide in the Arabian Sea. Deep-Sea Research 38:871-890

Naqvi, S W A, R Sen Gupta (1985) 'NO', a useful tool for the estimation of nitrate deficits in the Arabian Sea. Deep-Sea Research 32:665-674

Naqvi S W A, M S Shailaja (1993) Activity Of The Respiratory Electron-Transport System And Respiration Rates Within The Oxygen Minimum Layer Of The Arabian Sea. Deep-Sea Research Part Ii-Topical Studies In Oceanography 40:687-695

Nicholls J C, I M Davies, M Trimmer (2007) High-resolution profiles and nitrogen isotope tracing reveal a dominant source of nitrous oxide and multiple pathways of nitrogen gas formation in the central Arabian Sea. Limnology and Oceanography 52:156-168

Ogilvie B G, M Rutter, D B Nedwell (1997) Selection by temperature of nitrate-reducing bacteria from estuarine sediments: species composition and competition for nitrate. FEMS Microbiology Ecology 23:11-22

Otte S, N G Grobben, L A Robertson, M S M Jetten, J G Kuenen (1996) Nitrous oxide production by Alcaligenes faecalis under transient and dynamic aerobic and anaerobic conditions. Applied And Environmental Microbiology 62:2421-2426

Parsons T R, Y Maita, C M Lalli (1984) A Manual of Chemical and Biological Methods for Seawater Analysis, Vol. Pergamon Press, Oxford

Payne W J (1973) Reduction of nitrogenous oxides by microorganisms. Bacteriological Reviews 37:409-452

Saagar P M, H J W De Baar, R J Howland (1992) Cd, Zn, Ni and Cu in the Indian Ocean. Deep-Sea Research 39:9-35

Thamdrup B, T Dalsgaard, M M Jensen, O Ulloa, L Farias, R Escribano (2006) Anaerobic ammonium oxidation in the oxygen-deficient waters off northern Chile. Limnology And Oceanography 51:2145-2156

Theberge S M, G W Luther, A M Farrenkopf (1997) On the existence of free and metal complexed sulfide in the Arabian Sea and its oxygen minimum zone. Deep-Sea Research 44:1381-1390 
Ward, B B, J Granger, M T Maldonado, K L Casciotti, S Harris and M L Wells (2005) Denitrification in the hypolimnion of permanently ice-covered Lake Boney, Antarctica Aquatic Microbial Ecology 52:197-205

Witter A E, B L Lewis, G W Luther (2000) Iron speciation in the Arabian Sea. Deep-Sea Research Part Ii-Topical Studies In Oceanography 47:1517-1539

Wu, J, E A Boyle (1998) Determination of iron in seawater by high-resolution isotope dilution inductively coupled plasma mass spectrometry after $\mathrm{Mg}(\mathrm{OH})_{2}$ coprecipitation. Analytica Chimica Acta 267:183-191

Zumft W G (1997) Cell biology and molecular basis of denitrification. Microbiology and Molecular Biology Reviews 61:533-616 
Table 1. Station locations and characteristics

\begin{tabular}{|c|c|c|c|c|c|c|c|c|c|}
\hline Station & LONG & $\overline{\text { LAT }}$ & $\begin{array}{c}\text { Sampling } \\
\text { Depth } \\
\text { (m) }\end{array}$ & $\mathrm{T}^{0} \mathrm{C}$ & $\bar{S}$ & $\begin{array}{c}\mathrm{O}_{2} \mu \mathrm{mol} \\
\mathbf{k g}^{-1} \\
\text { CTDprobe }\end{array}$ & $\begin{array}{l}\text { Copper } \\
\text { nM kg-1 }\end{array}$ & $\begin{array}{l}\mathrm{NO}_{3}^{-} \\
(\mu \mathrm{M})\end{array}$ & $\begin{array}{l}\mathrm{NO}_{2}^{-} \\
(\mu \mathrm{M})\end{array}$ \\
\hline \multicolumn{10}{|l|}{$\overline{E T N P}$} \\
\hline 15 & $105.72 \mathrm{~W}$ & $18.43 \mathrm{~N}$ & 100 & 12.98 & 34.82 & 2.68 & 1.06 & 25.2 & 2.6 \\
\hline 21 & $119.00 \mathrm{~W}$ & $15.03 \mathrm{~N}$ & 185 & 11.78 & 34.74 & 2.79 & 1.25 & $\sim 25$ & 1.7 \\
\hline \multicolumn{10}{|l|}{ ETSP } \\
\hline 9 & $75.13 \mathrm{~W}$ & $15.63 \mathrm{~S}$ & 250 & 11.48 & 34.83 & 0.56 & ND & $\sim 18$ & 3.15 \\
\hline 32 & $78.17 \mathrm{~W}$ & $11.00 \mathrm{E}$ & 250 & 11.98 & 34.87 & 0.56 & ND & $\sim 22$ & 3.5 \\
\hline \multicolumn{10}{|c|}{ Arabian Sea } \\
\hline 1 & $68.00 \mathrm{E}$ & $17.00 \mathrm{~N}$ & 230 & 14.16 & 35.39 & 2.79 & 1.2 & 25.5 & 5.2 \\
\hline 2 & $64.00 \mathrm{E}$ & $19.80 \mathrm{~N}$ & 276 & 16.44 & 35.97 & 3.15 & 1.9 & 23.5 & 1.1 \\
\hline 17 & $57.55 \mathrm{E}$ & $18.37 \mathrm{~N}$ & 175 & 16.50 & 35.86 & 2.68 & ND & 24.5 & 0.04 \\
\hline 23 & $64.00 \mathrm{E}$ & $15.00 \mathrm{~N}$ & 250 & 16.67 & 35.71 & 2.60 & 2.1 & 19.8 & 2.4 \\
\hline
\end{tabular}


Table 2 Growth and DIN transformation rates in big bag incubations

1. growth rates

computed from "exponential" portion of cell number curve

\begin{tabular}{|c|c|c|c|c|c|c|}
\hline Station & treatment & interval $(\mathrm{h})$ & $\mathrm{k}($ per h) & R2 & $\begin{array}{l}\text { generation } \\
\text { time }(\mathrm{h})\end{array}$ & $\mathrm{N}$ \\
\hline \multirow[t]{4}{*}{ ETSP } & $C$ & $0-35$ & 0.022 & 0.94 & 45 & 3 \\
\hline & C & $0-35$ & 0.021 & 0.99 & 48 & 3 \\
\hline & $\mathrm{C}+\mathrm{Cu}$ & $0-59$ & 0.021 & 0.96 & 48 & 4 \\
\hline & $\mathrm{C}+\mathrm{Cu}$ & $0-59$ & 0.018 & 0.98 & 56 & 4 \\
\hline \multirow[t]{4}{*}{ AS2 } & control & $27-143$ & 0.008 & 0.93 & 123 & 4 \\
\hline & control & $27-143$ & 0.007 & 0.82 & 135 & 4 \\
\hline & $\mathrm{Cu}$ & $27-143$ & 0.006 & 0.85 & 156 & 4 \\
\hline & $\mathrm{Cu}$ & $27-143$ & 0.012 & 0.85 & 82 & 4 \\
\hline AS17 & Control & $0-67$ & 0.017 & 0.96 & 59 & 4 \\
\hline \multirow[t]{4}{*}{ AS23 } & control & $21-122$ & 0.013 & 0.87 & 75 & 4 \\
\hline & control & $21-122$ & 0.015 & 0.91 & 68 & 4 \\
\hline & $\mathrm{Cu}$ & $21-122$ & 0.012 & 0.87 & 84 & 4 \\
\hline & $\mathrm{Cu}$ & $21-122$ & 0.014 & 0.96 & 71 & 4 \\
\hline
\end{tabular}

Notes: Cell abundance data for ETNP, AS1 and most treatments at AS17 not adequate to estimate growth rates

\section{Rate of nitrate reduction per cell during exponential phase} max rates from steepest decline in $\mathrm{NO} 3$

\begin{tabular}{ll} 
Station & treatment \\
\hline ETNP & C, C+Cu \\
ETSP & C, C+Cu \\
AS1 & C, C+Cu \\
AS2 & control, Cu \\
AS17 & control \\
AS23 & control. $\mathrm{Cu}$
\end{tabular}

\begin{tabular}{|c|c|c|}
\hline ave & stdev & $\mathrm{N}$ \\
\hline n.d. & & \\
\hline $3.4 \mathrm{E}-08$ & $1.2 \mathrm{E}-08$ & 4 \\
\hline $1.6 \mathrm{E}-08$ & 5.9E-09 & 8 \\
\hline $3.2 \mathrm{E}-08$ & $2.0 \mathrm{E}-08$ & 4 \\
\hline $4.5 \mathrm{E}-08$ & & 2 \\
\hline $3.5 \mathrm{E}-08$ & $1.6 \mathrm{E}-08$ & 7 \\
\hline
\end{tabular}

Note: ETNP rates not computed because inadequate cell abundance data

\section{Rate of nitrite reduction per cell during exponential phase}

max rates from steepest decline in $\mathrm{NO} 2$

\begin{tabular}{ll} 
Station & treatment \\
\hline ETNP & $\mathrm{C}, \mathrm{C}+\mathrm{Cu}$ \\
ETSP & $\mathrm{C}, \mathrm{C}+\mathrm{Cu}$ \\
AS1 & $\mathrm{C}, \mathrm{C}+\mathrm{Cu}$ \\
AS2 & control, $\mathrm{Cu}$ \\
AS17 & control \\
AS23 & control. $\mathrm{Cu}$
\end{tabular}

\begin{tabular}{|c|c|c|}
\hline $\begin{array}{c}\mu \mathrm{molNO} 2 / \text { cell/dy } \\
\text { ave }\end{array}$ & stdev & $\mathrm{N}$ \\
\hline n.d. & & \\
\hline 7.9E-09 & $1.4 \mathrm{E}-09$ & 4 \\
\hline $7.3 \mathrm{E}-09$ & & 2 \\
\hline $2.1 \mathrm{E}-08$ & $7.8 \mathrm{E}-09$ & 4 \\
\hline $\begin{array}{r}\text { n.d. } \\
1.5 \mathrm{E}-08\end{array}$ & 6.0E-09 & 6 \\
\hline
\end{tabular}

Notes: ETNP rates not computed because inadequate cell abundance data

AS17 did not go through complete NO2 depletion so rates cannot be computed

\section{Absolute NO3 reduction rates (single highest rate for each treatment)}

\begin{tabular}{ll} 
Station & treatments \\
\hline ETNP & $\mathrm{C}, \mathrm{C}+\mathrm{Cu}$ \\
ETSP & $\mathrm{C}, \mathrm{C}+\mathrm{Cu}$ \\
AS1 & $\mathrm{C}, \mathrm{C}+\mathrm{Cu}$ \\
AS2 & control, $\mathrm{Cu}$ \\
AS17 & control \\
AS23 & control, $\mathrm{Cu}$
\end{tabular}

\begin{tabular}{rrr}
$\mu \mathrm{mol} / \mathrm{L} / \mathrm{dy}$ & & \\
ave & stdev & $\mathrm{N}$ \\
\hline 20.6 & 5.8 & 6 \\
17.7 & 1.6 & 4 \\
7.8 & 3.3 & 8 \\
9.7 & 1.9 & 4 \\
6.8 & 3.2 & 4 \\
14.0 & 3.3 & 4
\end{tabular}

Maximum rates for listed treatments were averaged 

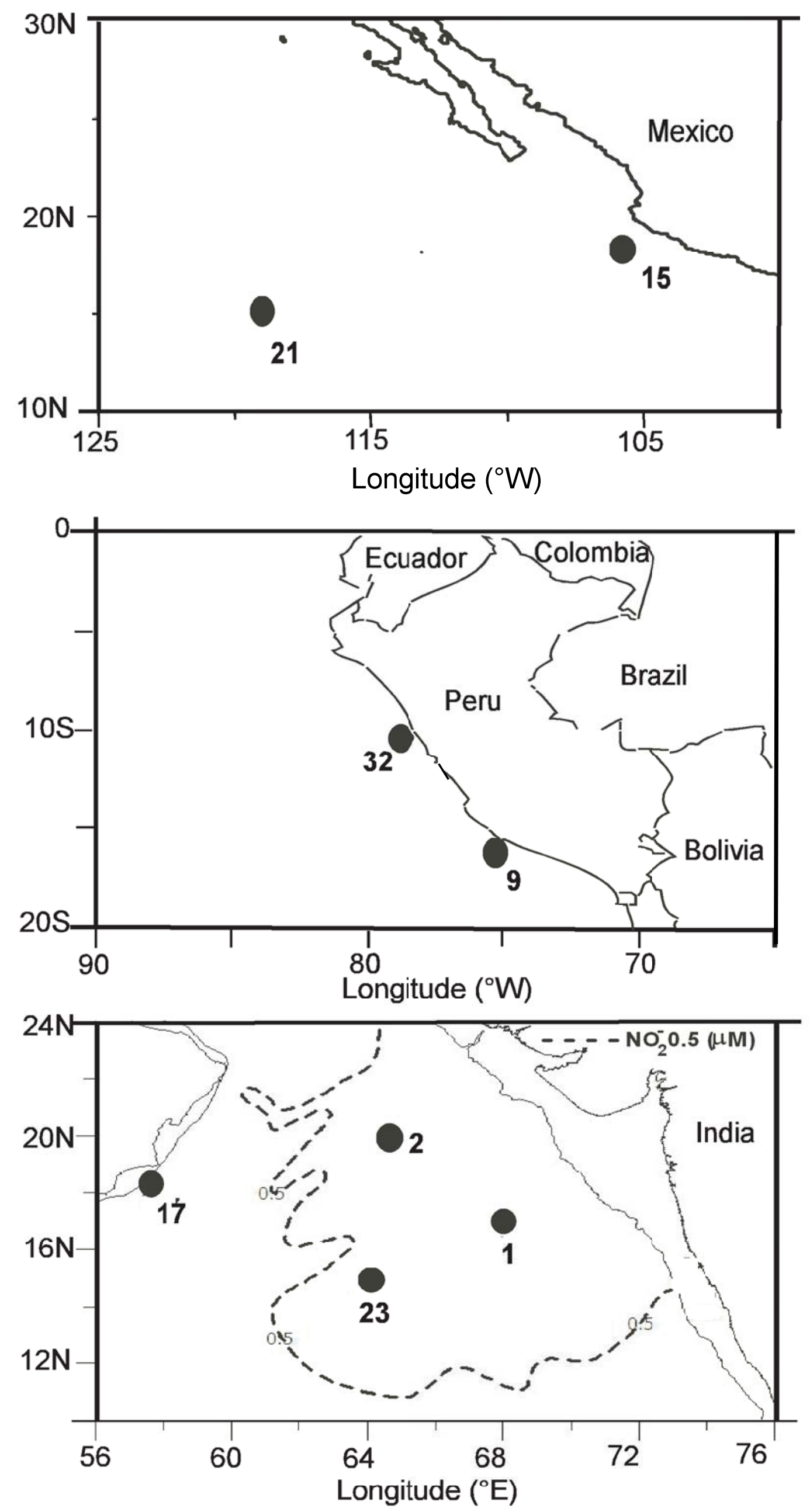
ETNP Station 15
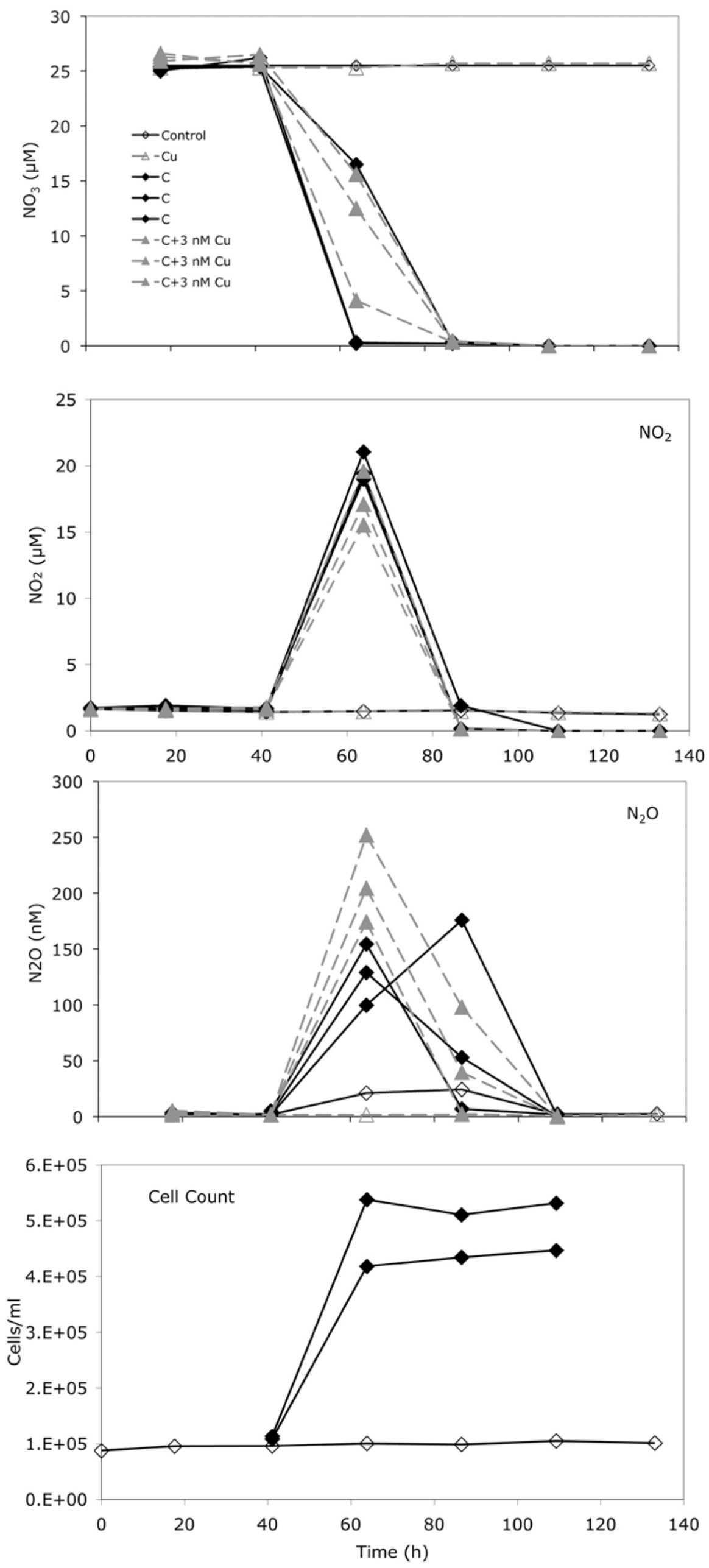
ETSP Station 9
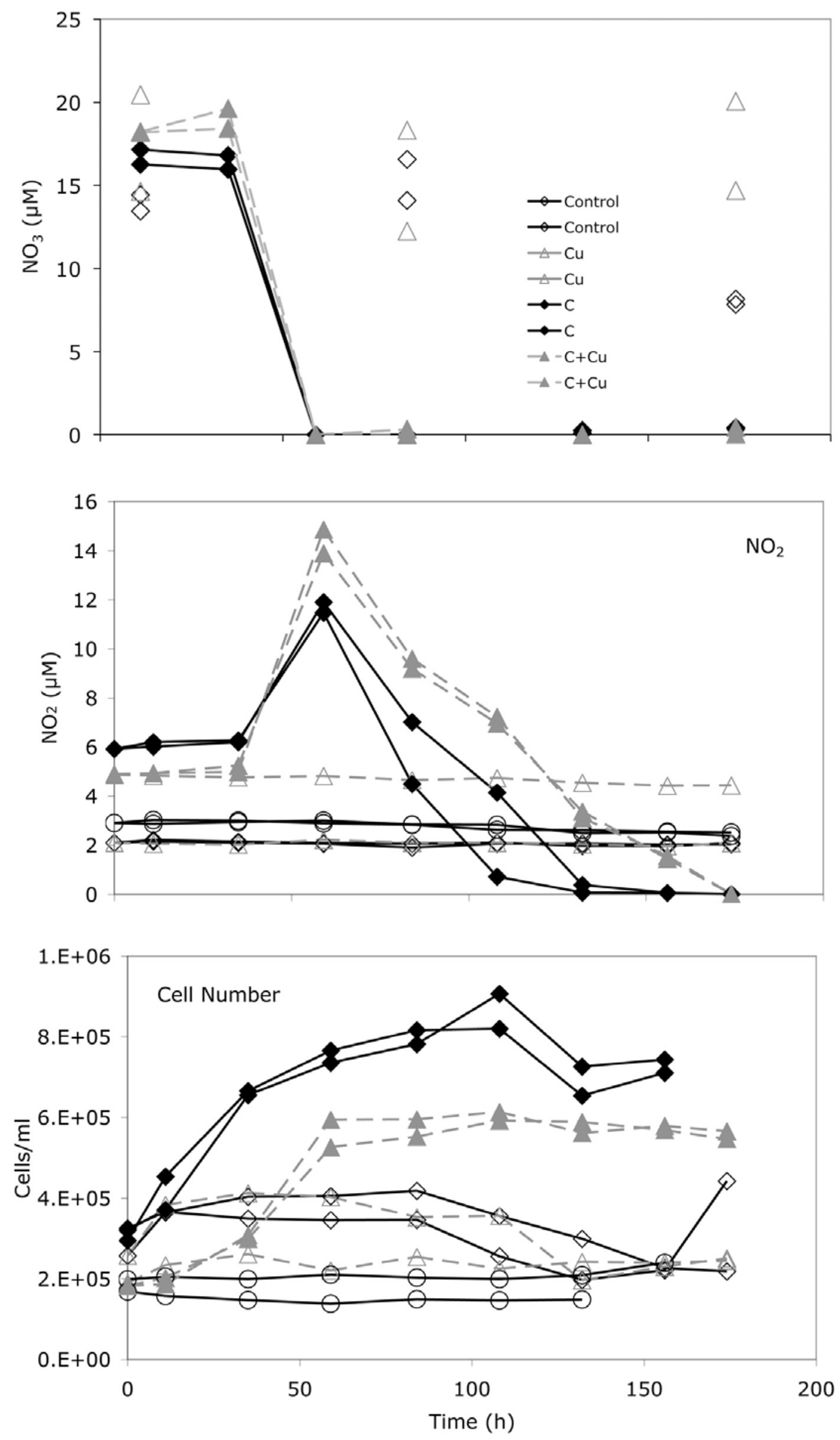
Arabian Sea Station 1
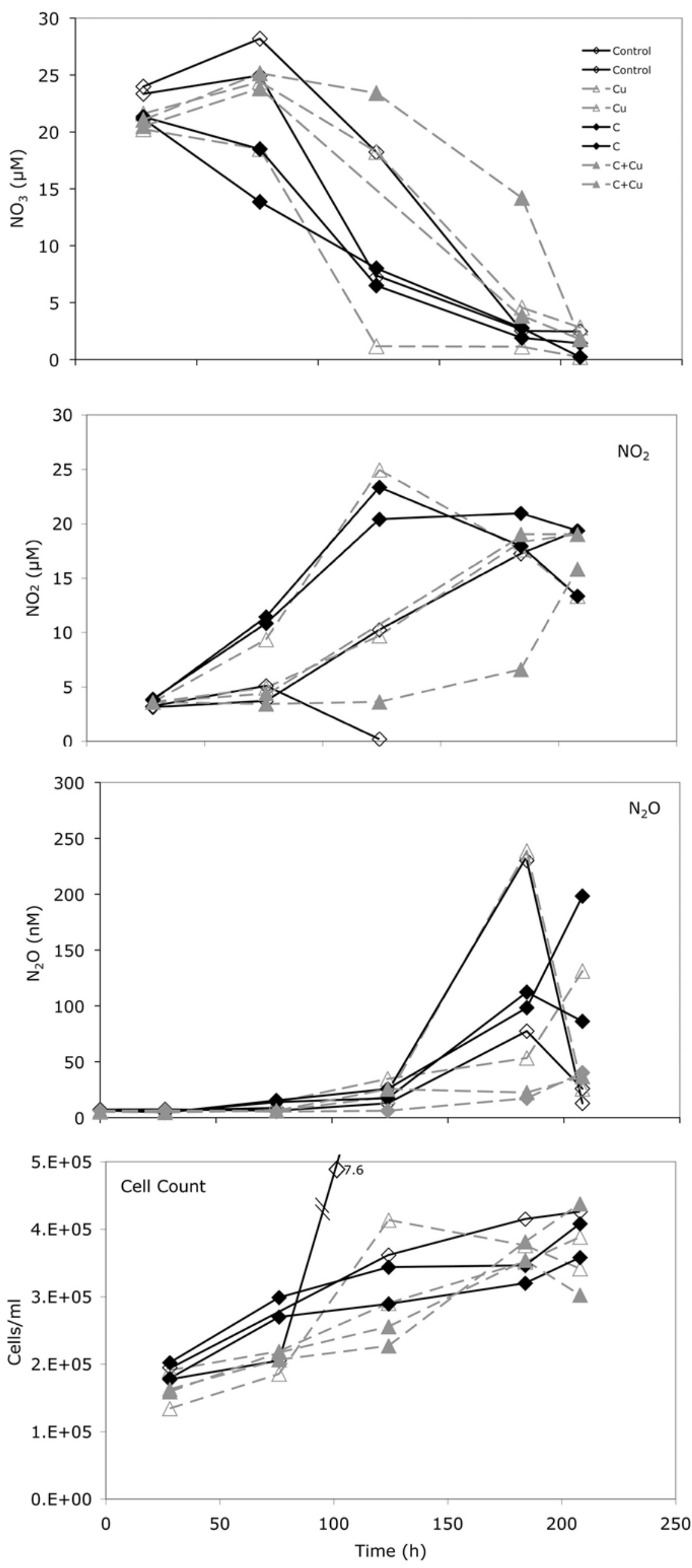

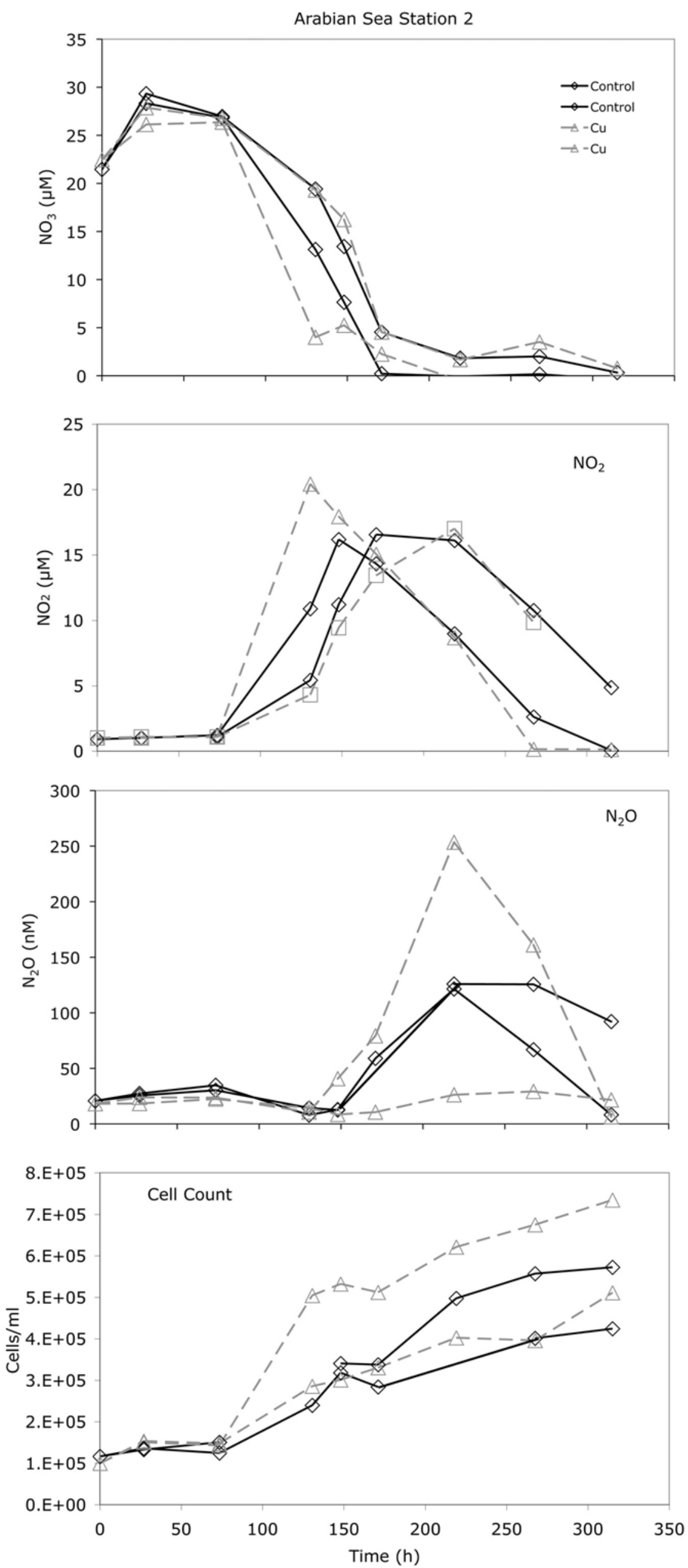
Arabian Sea Station 17
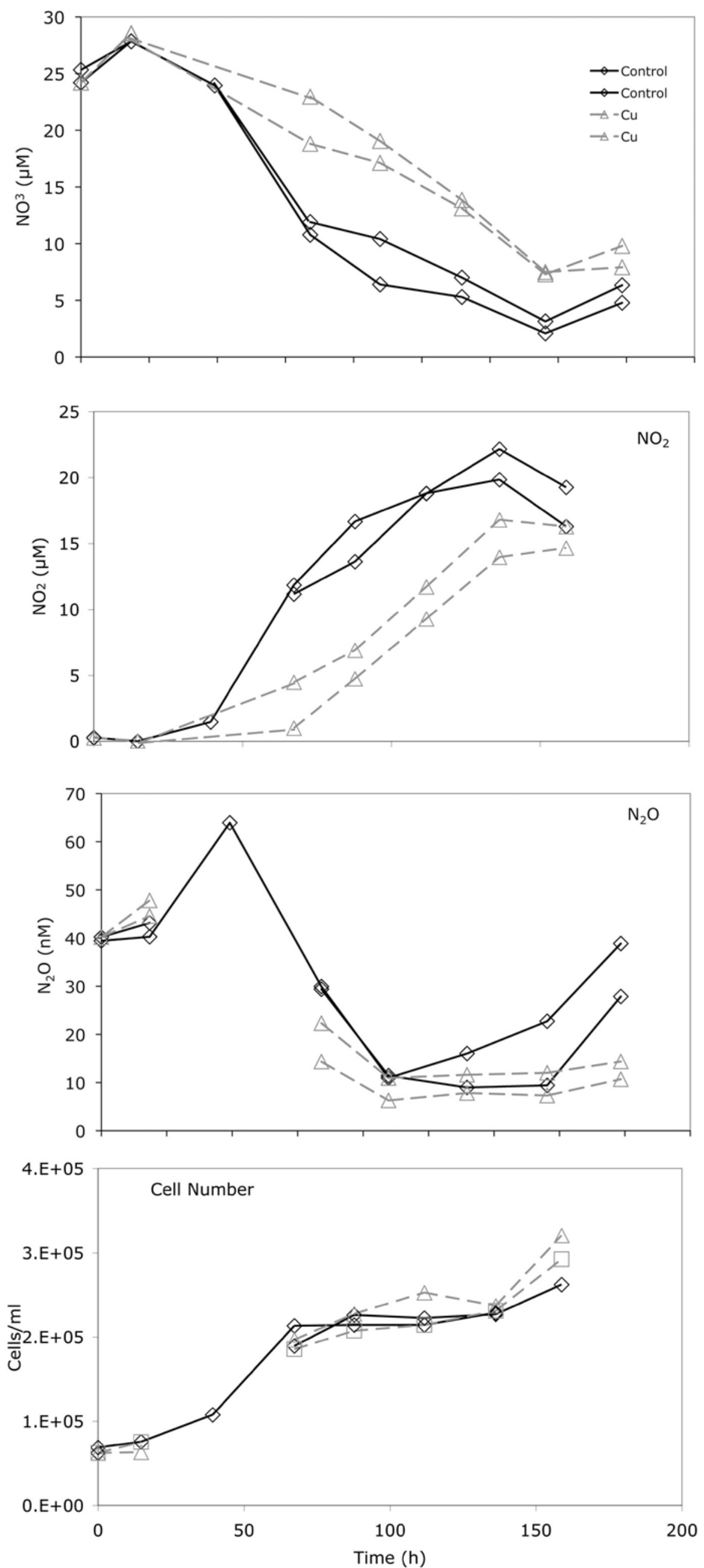